\title{
LECTURER QUALITY EMPOWERMENT STRATEGY IN REALIZING NATIONAL EDUCATION OBJECTIVES
}

\author{
M. Rosul Asmawi \\ m.rosulasmawi@yahoo.co.id \\ Lecturer at Program Pascasarjana Universitas Islam Syekh-Yusuf Tangerang, Indonesia.
}

\begin{abstract}
This study aims to find out the position and role of lecturers in carrying out the task of implementing the national education system and realizing the goals of national education. Lecturers are one of the determinants of the quality of education. The success of the implementation of higher education is largely determined by the readiness of the lecturer in preparing their students through teaching and learning activities or the learning process. The strategic position of lecturers to improve the quality of educational outcomes is strongly influenced by professional abilities in teaching and their level of welfare. To realize this; then the strategy of empowering lecturers is needed in order to realize professionalism that can be accounted for. The empowerment strategy implemented will be able to raise the dignity and level, improve the quality of learning, improve the quality of national education and provide quality services. Empowerment of lecturers is intended to create a work atmosphere or climate that leads to the development of potential, empowerment, and protection.
\end{abstract}

Keywords: educator certification; fulfillment of lecturer rights and obligations; procurement, coaching and lecturer development; appreciation and guarantee of lecturer protection; strengthening lecturer equality, strengthening government and regional government responsibilities and obligations.

\section{A. Introduction}

Changes and dynamics of the life of global society today is happening very rapidly in line with the development of advances in science and technology and the swift flow of information that penetrates all walks of life. Likewise with what happens in the field of education, where the National Education System Law and the Law on Teachers and Lecturers are expected to be able to answer the challenges of the ever changing times. Changes in the field of education should be addressed as a positive change; bearing in mind the issue of educational development in Indonesia has been very complex. The amendment to the Law on the National Education System, which was then followed by the Law on Teachers and Lecturers is the implementation of the mandate of the 1945 Constitution of the Republic of Indonesia, where the government strives and organizes a national education system that increases faith and piety in God and noble character in order to educate the life of the nation.
To achieve national development in the field of education that can guarantee expansion and equitable access, increase in quality and relevance, as well as good governance and educational accountability that are able to face challenges in accordance with the demands for change, and live local, national and global needs to be empowered and improved lecturers planned, directed and continuous.

The quality of humanity needed by the Indonesian people in the future is able to face the competition that is as tight as any other nation in the world. Therefore the lecturer has a very strategic function, role and position. The lecturer as an educator is a professional, who has a vision of the realization of the implementation of learning in accordance with the principles of professionalism to fulfill the same rights for every citizen in obtaining quality education.

Based on the description above, the recognition of the position of lecturers as professionals has a mission to implement the objectives of the Teacher and Lecturer Law as follows: 
1. To appoint lecturer dignity;

2. Guarantee the rights and obligations of lecturers;

3. Improving lecturer competence;

4. Promote the profession and career of lecturers;

5. Improving the quality of learning;

6. Improving the quality of national education;

7. Reducing the gap in the availability of lecturers between regions in terms of quantity, quality, academic qualifications and competencies;

8. Reducing disparities in the quality of education between regions; and

9. Improving quality education services.

Based on this vision and mission, the position of lecturers as professionals serves to improve the dignity of lecturers and develop science, technology and art. In line with this function, the position of lecturers as professionals aims to implement the national education system and realize national education goals; namely the development of the potential of students to become people of faith and piety, noble, healthy, knowledgeable, capable, creative, independent, and to become democratic and responsible citizens. To realize this; then the strategy of empowering lecturers is needed in order to realize professionalism that can be accounted for. Empowerment of lecturers has a goal as explained by Hasan (2002: 2-3) that: "In empowering the community there are three important things that need to be understood together, namely: (a) creating an atmosphere or climate that enables the potential of a developing community. (b) strengthening the potential or empowering (empowering) the community; and (c) empower contains the notion of protecting. This means that in the process of empowerment the weak ones must be prevented from getting weaker ".

\section{Formulation of the Problem}

The strategy of empowering lecturers is a very important variable in order to realize the national education system and realize the goals of national education, so as to strengthen the position of lecturers as professionals. Therefore the issues to be examined are as follows: (1) how is the educator certification strategy based on academic qualifications and professional competence; (2) how is the strategy to fulfill the rights and obligations of lecturers as professional staff in accordance with the principles of professionalism; (3) the extent to which the implementation of strategic policies in the procurement of lecturers; (4) how is the strategic implementation in fostering and developing lecturers to improve and serve; (5) what is the strategy for awarding and guaranteeing lecturer protection in carrying out professional assignments; (6) how to strengthen the equality of lecturers assigned to educational units held by the government and regional governments with lecturers assigned to educational units held by the public; (7) how to strengthen the responsibilities and obligations of the government and regional governments in realizing the achievement of the education budget to fulfill the rights and obligations of lecturers.

\section{B. Writing Purpose}

This study is expected to have two objectives; namely the general purpose and special purpose of writing. The general objective of writing is expected to be explored sources of thought and information on the strategy of empowering the quality of lecturers as professionals in supporting the realization of the national education system and realizing the goals of national education. The specific purpose of writing is to describe the strategy of empowering the quality of lecturers, seen from the seven aspects, namely: teacher certification, fulfillment of lecturers' rights and obligations, lecturer procurement, lecturer development and development, awarding and guaranteeing lecturer protection, strengthening lecturer equality, and 
strengthening responsibilities and the obligation of the government and regional governments in realizing the achievement of the education budget.

\section{Literature Review and Discussion}

\section{a. Educator Certification}

This educator certification concerns academic qualifications and professional competencies held by a lecturer. Regarding the qualifications of this lecturer explained by Chamidi (2001: 2-3) which states: "Lecturer qualifications are determined by variables such as the high level of education, suitability between the fields of study that have been taken with the field of study taught, the length of teaching experience, training that has been followed and research he had done ". In this case, lecturers are one of the most important factors affecting the quality of education; which by Suryadi (in Safrudin Chamidi, 2002: 4) calls it: "Qualified teacher, can be measured by five main factors namely professional ability, professional effort, time suitability devoted to professional activities, suitability between expertise and work and adequate welfare. Therefore improving the professional quality of teachers and lecturers is the most strategic effort in improving the quality of education at every type and level of education.

Actually the professionalism of the lecturer can be built in line with an adequate level of welfare. It must be admitted, that the lecturer professional would be difficult to achieve if he ignored aspects of meeting his needs. Meeting these needs is the right of lecturers mandated in the Teacher and Lecturer Law; where in Article 51 Paragraph (1) the lecturer is entitled to earn an income above the minimum living needs and guarantee of social welfare; that is, sufficient income to meet the living needs of lecturers and their families, be it clothing, food, housing, health, education, recreation and old age insurance.

Meeting the life and professional needs of the lecturer is not a guarantee to work optimally, but at least it will lead to better professional assignment conditions; so that the goals of national education as a process will be achieved with certainty. This opinion is reinforced by Chamidi (2002: 5) who argues: "A professional must be able to devote most of his attention to professional efforts, such as increasing expertise, enriching knowledge, and increasing work efficiency and effectiveness". Professional efforts need to be supported by adequate income and welfare in return for a professional. A decent income or welfare is absolutely necessary for a professional because the quality of their work is demanded by the parties served.

Professional skills of lecturers are measured by the highest education they have, while the time devoted to professional activities of lecturers is measured by teaching experience based on the academic level of the lecturer, consisting of expert assistants, lectors, chief lectors and professors (article 48 paragraph 2 of the Teacher Law and Lecturer).

Regarding lecturer certification this is not new to the world of higher education, which can be seen from the academic level of the lecturer it has. The higher academic position of the lecturer he is carrying, means showing the level of professionalism he has, as well as an educator's certificate. With reference to article 47 paragraph $1 \mathrm{c}$ of the Law on Teachers and Lecturers, whereby the teacher's education requirements for lecturers must be clearly owned; namely passing the certification carried out by universities. In this provision, apparently with educator certificates owned by lecturers is a new thing that must be taken. Educator's certificate for this lecturer is given after passing the certification, has an academic position of at least an expert assistant and has experience as a lecturer for at least 2 (two) years (article 47 paragraph 1 of the Teacher and Lecturer Law).

Dari tinjauan di atas, bagaimana dengan dosen yang sekarang memiliki gelar akademik, lektor kepala atau profesor? 
Apakah juga harus menemui setifikasi pendidik? Lebih profesional mana, dosen yang memiliki sertifikat pendidik undangan amanat pasal 47 ayat 1 Undang-Undang Guru dan Dosen, dengan dosen yang memiliki jabatan akademik lektor, lektor kepala atau profesor. Untuk menjelaskan pertanyaan itu, dapat ditarik sebuah logika; Jika disetujui, maka sertifikasi pendidik itu tidak memerlukan persetujuan yang panjang, maka pengaturannya harus diberlakukan untuk pengajar yang belum penyetaraan dan pengajar yang baru mendapatkan jenjang kepemimpinan akademik asisten ahli. Sementara dosen yang telah mendapatkan gelar akademik lektor, lektor kepala dan profesor tidak perlu mengikuti proses sertifikasi, namun harus diberikan sertifikat pendidik. Tidak logis jika dosen memiliki lektor akademik, lektor kepala dan profesor harus mengikuti proses sertifikasi. Sementara istilah sertifikat itu dinilai lebih rendah atau lebih rendah dari ijazah kesarjanaan dan jabatan akademik yang melekat padanya. Sertifikat, yang dalam bahasa Indonesia berarti sertifikat, sebagai bukti yang lazim diberikan pada seseorang yang telah menerima pelatihan keahlian; seperti pelatihan, kursus, seminar atau sertifikat penjaminan kualitas produk. Seperti yang disarankan terkait dengan budaya organisasi, seperti dikemukakan oleh Asmawi (2016:66) state culture organization is the concept of useful way of understanding management and performance in college. Thus how administrator can use the concept of culture to help solve specific administrative problem.

Next, what about the deed holder IV; owned by graduates of teacher training programs? In accordance with existing regulations, this deed IV is an educator certificate for the teaching permit program (Media Indonesia, Thursday 24 November 2005); who currently has become a lecturer. Therefore, deed IV is the same as the teacher certificate as referred to in article 45 of the Teacher and Lecturer Law; which if deemed irrelevant will cause disappointment among educators, which will certainly affect their tasks. At the time of enactment of this Act, the holder of deed IV who has not yet become a lecturer (new teacher) is still possible to participate in the certification process, as stipulated in article 47 paragraph (1) of the Teacher and Lecturer Law.

Educator certificate, certificate of competency or professional certificate is actually a single unit, where the certificate can be given to students and citizens in recognition of the competence to do certain jobs after passing the competency test; because it is called a competency certificate (article 61 paragraph 3 of the National Education System Law). The competency certificate is given to students or citizens; which is certainly different from educators for lecturers. Competency certificates for lecturers in professional programs must be held after a graduate in accordance with the level and area of expertise taught (article 31 paragraph 3 PP Number 19 of 2005 concerning National Education Standards).

With reference to the above study, this competency certificate relates to the area of expertise taught by the lecturer as a caregiver for the course; which means that a lecturer must have a good mastery of his field of expertise Educator's certificate as affirmed in article 1 paragraph (12) of the Teacher and Lecturer Law is formal evidence as acknowledgment given to lecturers as professional staff. In the teacher certification process, there are also aspects of competence as important for lecturers to become professionals. Competence is a set of knowledge, skills and behaviors that must be owned, internalized and mastered by lecturers in carrying out professional tasks. Because of that the training material in the educator competency process includes the aspects contained in the competency concept as follows:

1. Knowledge; namely awareness in the cognitive field. For example, a lecturer knows how to identify learning needs 
and how to learn from students according to their needs.

2. Understanding; namely the cognitive and affective depth possessed by the individual. For example, a lecturer who will carry out learning must have a good understanding of the characteristics and conditions of students, in order to carry out learning effectively and efficiently.

3. An ability is something that an individual has to carry out a task or work assigned to him. For example, the ability of lecturers to choose and make simple teaching aids to facilitate learning for students.

4. Value is a standard of behavior that has been believed and psychologically united in a person. For example the standard behavior of lecturers in learning (honesty, openness, democratic and others).

5. Attitudes, namely feelings (happy, not happy, like, dislike) or a reaction to a stimulus that comes from outside. For example, the reaction to the economic crisis, the feeling of increasing wages / salaries and so on.

6. Interest is the tendency of someone to do an action. For example, an interest in learning or doing something (Mulyana, 2002:38-39).

Selanjutnya, perguruan tinggi terakreditasi mana yang boleh meyelenggarakan proses pengadaan tenaga kependidikan, yang dalam pasal 47 ayat (2) dan ayat (3) UU Guru dan Dosen belum menyebut secara jelas, apakah program keguruan dan ilmu pendidikan atau program studi lain yang terakreditasi yang ada di suatu perguruan tinggi; yang sudah tentu diperlukan peraturan pelaksanaannya. Penetapan perguruan tinggi yang terakreditasi untuk menyelenggarakan program sertifikat pendidik untuk dosen ini hendaknya tidak membebani perguruan tinggi yang mengarah pada tambahan biaya tinggi, membebani biaya bagi dosen dan mempertimbngkan aspek waktu.

\section{b. Strategy for Fulfilling Lecturers' Rights and Obligations}

The rights and obligations of the lecturer as a professional are actually not new, but in the framework of empowering lecturers by improving their quality; is expected to provide greater acceleration in achieving accelerated national education goals; namely forming a society that has faith and piety to God Almighty and noble character in the context of intellectual life of the nation; which then the government issued a policy in the Law on Teachers and Lecturers.

Regulating the rights and obligations of the lecturer, one side wants to raise the dignity of the lecturer by providing a level of welfare above the minimum needs; It is also hoped that this professionalism can be realized in real terms in building the field of education which is currently very neglected. In order to realize the development of education, education funding is needed; which is a joint responsibility between the government and regional government, and the community (article 46 paragraph 2 of the Teacher and Lecturer Law) itself. Given that the community has limitations, especially in terms of funding; then based on the mandate of article 31 paragraph (4) of the 1945 Constitution of the Republic of Indonesia; the government and regional governments are responsible for providing an education budget of at least $20 \%$ of the APBN and APBD to meet the needs of national education.

The right of lecturers in carrying out this professional task is regulated in article 40 paragraph (1) of the National Education System Law and article 51 paragraph (1) of the Teacher and Lecturer Law; which basically involves income and guarantees, promotion and appreciation, protection, opportunities for improvement, freedom and scientific autonomy, freedom of graduation and freedom of association.

The interesting things from both of these Laws: (1) concerning income and welfare guarantees above the minimum 
needs (article 51 paragraph (1) a Teacher and Lecturer Law) or appropriate and adequate (article 40 paragraph (1) a Law National Education System Law) which will certainly burden the budget; especially for PTS; (2) to ease the burden on private tertiary institutions, the government provides professional allowances to lecturers who have an educator certificate (article 53 paragraph 1 of the Teacher and Lecturer Law), which is 1 (one) time the basic salary of lecturers appointed by the government at the level, length of service and the same qualifications (article 53 paragraph 2 of the Teacher and Lecturer Law); (3) the government provides subsidized functional allowances for private tertiary lecturers (article 54 paragraph 2 of the Teacher and Lecturer Law); (4) for private university lecturers who have the highest academic positions, namely professors are given an honorary allowance equivalent to 2 (two) times the basic salary of professors appointed by the government at the same level, tenure and qualifications (article 56 paragraph 1 of the Teacher and Lecturer Law ); and (5) the government and / local government guarantee the realization of additional benefits for lecturers, in the form of educational benefits, education insurance, scholarships, and awards, as well as the ease of obtaining education for sons / daughters, health services, and or other forms of welfare.

The rights of lecturers in the form of income and the provision of these allowances are aimed at raising the dignity of lecturers as professionals in carrying out the duty of realizing the objectives of national education, namely implementing tertiary education. In order to carry out the mandate of the law, implementing regulations are needed that clearly regulate the obligations of the government and regional governments in providing allowances to private university lecturers. The similarity of views between the government, local government and private universities in developing the field of education; namely achieving national education goals is the key to success in building Indonesian society.

\section{c. Lecturer Procurement Strategy}

Procurement is an activity of planning, acceptance, selection, appointment, placement, transfer and dismissal of employees in helping the company's goals (Asmawi, 2002: 8). With HR planning, it can be known with certainty the number of employee needs in a given year. After determining the needs are determined, then the recruitment is done. Likewise, in the implementation of recruitment lecturers are always carried out objectively and transparently (article 63 paragraph 1 of the Teacher and Lecturer Law), so that lecturers who have academic qualifications and competencies are required as required.

In this recruitment there are two interrelated needs; namely the needs of the organization and the needs of prospective employees. The organization requires employees to carry out work tasks, while prospective employees need jobs. To get prospective employees as desired, the organization should make these recruitment efforts so that prospective employees submit their applications. After the application is submitted, a selection can be made, so that prospective employees will be truly suitable. For prospective employees who are declared to have passed the selection process, then an appointment will be made in a position in a decision of the authorized official; which explains explicitly the placement of employees in a job. The procedures for appointment, placement, transfer, and dismissal of lecturers in educational units organized by the community should be regulated in staffing regulations based on applicable laws and regulations.

To ensure that the objective and transparent implementation of lecturer procurement should be regulated in the staffing regulations in such a way; including the implementation carried out consistently and correctly. Things that smell of $\mathrm{KKN}$ 
must be abandoned, because it will damage and harm the future of the community, nation and state.

\section{d. Lecturer Professional Development and Development Strategy}

As professionals, lecturers should get opportunities and opportunities to conduct business coaching and professional and career development, which includes pedagogical competencies, personal competencies, social competencies and professional competencies (article 69 paragraph 1 and paragraph 2 of the Teacher and Lecturer Law). Guidance and professional development of lecturers is carried out through functional positions (article 69 paragraph 3 of the Teacher and Lecturer Law) or lecturer academic level, starting from expert assistants, lecturers, chief lecturers and professors (article 48 paragraph 2 of the Teacher and Lecturer Law); while the guidance and career development of lecturers include assignments, promotions and promotions.

To guarantee the process of fostering and developing the profession and career of lecturers, it should be regulated in a strategic policy; which contains the rules of academic qualifications, competencies, professionalism, the certification process of educators and the service of lecturers; which of course not all lecturers can do it themselves. For this reason, arrangements are needed that involve responsibility for coaching, budgeting (funding) together between the government, regional government and the community (article 71 paragraph 1, paragraph 2 and paragraph 3 ). Regarding educator certificates as explained in article 47 paragraph (1), a new lecturer can be given an educator certificate after having an academic position of at least an expert assistant and passing the certification process; while in article 69 paragraph (3) it explains the development and professional development of lecturers through functional positions; which includes pedagogical competence, personal competence, social competence and professional competence (article 69 paragraph 2). If we look carefully, it seems that there are things that are not quite right between article 47 paragraph (1) and article 69 paragraph (2) and paragraph (3) of the Teacher and Lecturer Law; that is one side of the functional position as one of the requirements for obtaining an educator certificate, while on the other hand the guidance and professional development of lecturers is carried out through functional positions; which can be done by providing pedagogical competency material, personality competence, social competence and professional competence.

Therefore there must be strict implementation rules, that the certificate of educator can only be given to lecturers, after having a functional position of at least an expert assistant and passing the certification process; whereas lecturers whose functional positions at the time of the enactment of the Teacher and Lecturer Law already have functional positions of the lecturer and above do not need to follow the certification process; as stipulated in article 69 paragraphs (2) and (3), namely as a form of coaching and developing lecturers. which are carried out through functional positions.

The guidance and professional development and career of the lecturer must be contained in the workload of lecturers at least commensurate with 12 semester credit units (credits) and a maximum of 16 credits; which spreads on learning planning, learning process implementation, learning evaluation, guiding and training, research, additional tasks and community service. This even distribution within the workload of lecturers sometimes experiences many obstacles, therefore the head of the education unit has the authority to implement the teaching and professional development and career development strategies of lecturers in a continuous planning program.

e. Awarding Strategy and Protection Guarantee 
With good coaching and development efforts, it will produce lecturers who are outstanding, are exceptionally dedicated and I or work in special areas entitled to receive awards; which can be given by higher education units, district / city level, provincial level, national and / or international level (article 73 paragraph 1 and article 74 paragraph 1 and 2 of the Teacher and Lecturer Law).

To determine lecturers with outstanding achievements, exceptional dedication and / or assignments in special areas, it is necessary to make clear requirements and criteria so that each lecturer knows and understands well. These requirements and criteria will provide motivation and scientific innovation for lecturers to pursue professional careers; the form of the award has adequate value such as honors, special promotions, financials, certificates and / or other forms of awards. Regarding this award, especially the financial form, should be included in the APBN, APBD and APB items of the education unit; the implementation of which is based on input from the education unit organized by the community and government in each fiscal year; the gift of which commemorates the anniversary of the independence of the Republic of Indonesia, provincial anniversary, regency / city anniversary, anniversary of higher education unit, national education day and / or other holidays (article 74 paragraph 4 of the Law on Teachers and Lecturers ).

As professionals, lecturers in carrying out their duties must be given protection by the government, regional governments, professional organizations and / or higher education units which include legal protection, professional protection, as well as occupational safety and health protection. This protection for lecturers is intended to be able to carry out their duties with a sense of calm and seriousness in carrying out the objectives of national education.

\section{f. Strengthening Equality Lecturers of state universities and lecturers of private universities}

Strengthening equality is the principle of equality and balance, both from the juridical aspect and from the income aspect for lecturers. From the juridical aspect of professionalism, this state university lecturer and private university lecturer has equality that is regulated based on applicable laws and regulations. The distinguishing aspect lies in the employment status, where PTN lecturers are appointed by the government / regional government, while PTS lecturers are appointed by the PTS concerned. This difference will be evident in the income it receives, which allows PTS lecturers to be smaller than state tertiary lecturers. However, the opposite may occur, where higher education lecturers are greater than state tertiary lecturers.

To bridge the gap between state university lecturers and private university lecturers, the Teacher and Lecturer Law mandates the government and regional governments to provide allowances for state university lecturers budgeted in the State Budget and Regional Budget. For private university lecturers it seems that there are relatively no problems in terms of income, given that the provision of income is regulated in accordance with applicable regulations. But for private university lecturers it is necessary to be clear which aspects of income are received from the government and regional governments, including the amount. Private universities should no longer ask the government / regional government which is the right of the lecturer. Therefore, to realize the obligations of the government and regional government, clear and transparent regulations are needed.

For state tertiary lecturers who are seconded, placed or assigned to PTS, the income received should not be double, get a salary as a civil servant status and get a salary / income from the state university that is placed. This is very important so that 
social inequalities no longer arise as they occur today. Because of that what has been accepted as a lecturer in a state university, no longer receives salary / income from a private tertiary institution; except benefits that have not been given by the government.

\section{g. Strengthening the Responsibilities and Obligations of the Government and Regional Governments}

Strengthening the responsibilities and obligations of the government and regional governments in realizing the achievement of the education budget to fulfill the rights and obligations of the lecturer is the mandate of the law that must be implemented, which in fact is included in the preparation of the APBN and APBN. For this implementation indeed requires government regulations governing it. With this regulation, it will be clear what are the rights and obligations, including the rights and obligations of lecturers.

The initial steps being undertaken by the government; especially for Kopertis is lecturer data collection by giving a national lecturer ID number (NIDN). With this NIDN, a lecturer can be known from the college of origin and what functional position; which can be used as a reference for granting benefits by the government or regional government. Furthermore, regulations in the form of government regulations or other implementing regulations are needed as a follow up to the Teacher and Lecturer Law.

Without the willingness and sincerity of the government and regional governments, this positive law is only a written regulation that has no real meaning and benefit. If this has also not been done, it will actually make national development; especially in developing the nation will be far behind the progress and growth and development of developed countries in the world; which Indonesian workers will become artisans in their own country.

\section{Conclusions and Suggestions}

\section{a. Conclusions}

Lecturers are one of the determinants of the high and low quality of educational outcomes. The success of the organization of higher education is very much determined by the extent of the readiness of the lecturer in preparing their students through teaching and learning activities or the learning process. However, the strategic position of lecturers to improve the quality of educational outcomes is strongly influenced by their professional teaching abilities and level of welfare; which can be done with an empowerment strategy. In contrast to the opinion of Asmawi (2018: 33-34) "Basic education is the basis of lifelong learning and human development, and on that basis, countries can build systematically the level of further education and training", which is done by the teacher namely in basic education, in universities carried out by lecturers.

To obtain policy inputs that can be used as a reference and reference for efforts to improve the quality of lecturers in connection with the enactment of the National Education System Law and the Law on Teachers and Lecturers in 2006. Through this study can be summarized as follows:

First, the educator certificate and this competency certificate have a basis in common; which means that a lecturer must have a good mastery of his field of expertise Educator's certificate is formal evidence as an acknowledgment given to the lecturer as a professional. In the teacher certification process, there are also aspects of competence as important for lecturers to become professionals. Competence is a set of knowledge, skills and behaviors that must be owned, lived and mastered by lecturers in carrying out professional tasks; which means that the certificate of educator and certificate of competence is to have security. Therefore, the training material in the process of educator competence includes aspects contained in the concept of 
Padagogic, Personality, Social and Professional Competencies; which in more detail such as: (a) knowledge (knowledge); (b) understanding (undestanding); (c) ability (skill); (d) value (value); (e) attitude (attitude); and (f) interest (intrest). The educator certification process by including the training material as above, can be carried out by universities whose study programs have been accredited, taking into account aspects of functional position, costs and implementation time; where for those who already have. Functional positions should be given direct lecturer certification according to the level of functional positions without having to attend training, except for teaching staff who have not been equalized. In realizing this certification process it should be borne by the government and local government budgets.

Second, the fulfillment of lecturers' rights and obligations as professional staff is intended to provide empowerment by improving their quality; so as to provide a greater acceleration in achieving the acceleration of national education goals. Lecturer rights in the form of income and the provision of allowances are intended to raise the dignity of lecturers. In order to carry out the mandate of the law, it requires implementing regulations that clearly regulate the obligations of the government and regional governments in providing benefits; including the amount to PTS lecturers. The similarity of views between the government, regional government and PTS in developing the field of education; namely achieving national education goals is the key to success in building Indonesian society.

Third, to get lecturers as professionals, a procurement process should be carried out through a good selection process in accordance with the specified requirements and qualifications. To ensure that the objective and transparent implementation of lecturer procurement should be regulated in the staffing regulations in such a way; included in the selection that is carried out consistently and correctly. Things that smell of KKN must be abandoned, because it will damage and harm the future of the community, nation and state.

Fourth, there are things that are not quite right between article 47 paragraph (1) and article 69 paragraph (2) and paragraph (3) of the Teacher and Lecturer Law; that is one side of the functional position as one of the requirements for obtaining an educator certificate, while on the other hand the guidance and professional development of lecturers is carried out through functional positions; which can be done by providing pedagogical competency material, personality competence, social competence and professional competence.Kelima, penghargaan dan perlindungan bagi dosen merupakan kebutuhan bagi setiap orang, termasuk bagi dosen.

Fifth, this award is closely related to work performance, because it is not possible for lecturers whose achievements are lacking to be given rewards. As professionals, lecturers in carrying out their duties must be given protection by the government, regional governments, professional organizations and / or higher education units which include legal protection, professional protection, as well as occupational safety and health protection. This protection is intended so that lecturers can carry out their duties with a sense of calm, security and seriousness in carrying out their duties to achieve the objectives of national education.

Sixth, the equality of PTN lecturers and PTS lecturers appears to exist, namely from the juridical aspects of professionalism and employment status. The equivalence of these PTN lecturers and PTS lecturers is regulated based on applicable laws and regulations. The distinguishing aspect will be clearly seen in the income it receives. Therefore, this principle of equality must be truly implemented in a real way so that it does not cause major social problems.

Seventh, to actualize and in order to raise the dignity, lecturer dignity, quality of 
learning, quality of national education and improve quality education, it is necessary to strengthen the responsibilities and obligations of the government and regional governments in realizing the education budget to fulfill the rights and obligations of lecturers, as mandated the law, the reality of which is included in the preparation of the APBN and APBN. For this implementation indeed requires government regulations governing it. With this regulation, it will be clear what are the rights and obligations, including the rights and obligations of lecturers. Without the support of an adequate education budget, it will have difficulty realizing that national education goal.

\section{b. Suggestions}

In order to achieve the quality of education for students as the goal of national education, namely the development of the potential of students to become human beings who have faith and be devoted to God, virtuous, healthy, knowledgeable, competent, creative, independent, and become democratic citizens and responsible, the role of lecturers is needed as a determinant of the learning process.

The National Education System Act and the Teachers and Lecturers Act which provides recognition of the position of lecturers as professionals work to improve the dignity, dignity, and role of lecturers in the learning process, the development of science, technology and arts, as well as community service functions to improve quality of national education. To realize this, some suggestions include:

1. Educator certificate and / or competency certificate which is an acknowledgment of the position of lecturer as a professional, can be done through coaching and development, which in the certification process really takes into account the competency qualifications through functional positions. Functional positions (academic positions) are also a form of recognition for a lecturer as a professional staff; which in the enactment of the Teacher and Lecturer Law should be more wise, prudent, not detrimental, and still have the relevance of the provisions that still apply. Terms that have the same meaning as this educator certificate such as a competent certificate and / or certificate.

2. As professionals, lecturers have the obligation to carry out learning tasks towards the achievement of national education goals; only then get their rights. However well the Teacher and Lecturer Law will not have any beneficial value, if the government and the regional government do not realize it clearly in the APBN and APBD regulations. Because of that, serious effort is needed by all parties in building the dignity, dignity and lecturers, and the quality of national education.

3 . The process of procuring lecturers can be done through a good selection stage in accordance with the specified requirements and qualifications. The objective and transparent implementation of lecturer procurement will guarantee the production of qualified lecturers. Should things that smell like real work lectures, these must be abandoned, because they will damage and harm the future of society, nation and state.

4. Things that do not quite fit between article 47 paragraph (1) and article 69 paragraph (2) and paragraph (3) of the Teacher and Lecturer Law; that is one side of the functional position as one of the requirements for obtaining an educator certificate, while on the other hand the guidance and professional development of lecturers is carried out through functional positions; then the solution is that the certification process must pay attention to the provisions that still apply. This certification process applies only to teaching staff who have just gained equalization with functional positions as expert assistants; while for 
lecturers who already have the functional lector above and above, it would be wiser if they did not have to follow the certification process, but directly given lecturer certificates.

5. Appreciation and protection for lecturers should not only be rules without reality. Because it is very logical and it is time for outstanding lecturers to be given proper awards; including protection so that the lecturer in carrying out his profession there is a guarantee of protection.

6. The problem faced by PTS lecturers lies in the extent to which the PTS concerned is able to provide a decent salary / income above the minimum needs. Therefore the responsibility of the government and regional governments to provide benefits as mandated by the law can be formulated properly; which of course needs to have clear regulatory regulations.

7. The responsibilities and obligations of the government and regional governments in realizing the education budget to fulfill the rights and obligations of lecturers, as mandated by the law, must be included in the preparation of the APBN and APBN. For this implementation requires government regulations. With this regulation, it will be clear what are the rights and obligations, including the rights and obligations of lecturers. Without adequate education budget support, realizing the goals of national education will be difficult to achieve.

\section{References}

Asmawi, M. Rosul. 2016. 'Organization Culture in the University, Study in Islamic SyekhYusuf University'. International Journal of Management and Administrative Sciences (IJMAS). (ISSN: 2225-7225). 3(04), (64-73).

Asmawi, M. Rosul. 2003. Manajemen Simber Daya Manusia, Suatu Pengantar. Tangerang: Fakultas Ilmu Sosial dan Ilmu Politik Universitas Islam Syekh-Yusuf Tangerang.

Asmawi, M. Rosul. 2018. 'Distance Education: A Challenge for Higher Education in Indonesia'. Jurnal Pancaran Pendidikan FKIP Universitas Jember. 7(1), 2018 (33-42).

Chamidi, Safrudin. 2001. Kualifikasi Dosen Pada Tahun 1999/2000. Jakarta: Jurnal Pendidikan dan Kebudayaan.

Chamidi, Safrudin. 2002. 'Urgensi Data dan Informasi Pendidikan, Kenyataan Serta Implikasinya di Era Desentralisasi'. Jakarta. Jurnal Pendidikan dan Kebudayaan.

Hasan, Suwarman Engking. 2002. 'Strategi Menciptakan Manusia yang Bersumber Daya Unggul. Jakarta'. Jurnal Pendidikan dan Kebudayaan.

Mulyana. 2002. Proses Belajar Mengajar. Bandung: Mandar Maju.

\section{Dokumen:}

Winarno. Jum'at 18 Nopember, 2005. (Online), diakses 18 Nopember 2005.

Media Indonesia. Kamis 24 Nopember, 2005. (Online), diakses 24 Nopember 2005.

Peraturan Pemerintah Republik Indonesia Nomor 19 Tahun 2005 Tentang Standar Nasional Pendidikan.

Undang Dasar Negara Republik Indonesia Tahun 1945.

Undang-Undang Republik Indonesia Nomor 32 Tahun 2003 Tentang Sistem Pendidikan

Nasional, Lembaran Negara Nomor 78, 2003 dan Tmabhan Lembaran Negara Nomor 4301.

Undang-Undang Republik Indonesia Nomor 14 Tahun 2005 Tentang Guru dan Dosen. 
